Giroux, J.-F., M. Patenaude-Monette, F. Lagarde, P. Mousseau, and F. Racine. 2016. Changes in spring arrival date and timing of breeding of Ringbilled Gulls in southern Québec over four decades. Avian Conservation and Ecology 11(1):1. http://dx.doi.org/10.5751/ACE-00821-110101 Copyright $(C) 2016$ by the author(s). Published here under license by the Resilience Alliance.

Research Paper

\title{
Changes in spring arrival date and timing of breeding of Ring-billed Gulls in southern Québec over four decades
}

\author{
Jean-François Giroux ${ }^{1}$, Martin Patenaude-Monette ${ }^{2}$, Florent Lagarde ${ }^{2}$, Pierre Mousseau ${ }^{3}$ and François Racine ${ }^{2}$ \\ ${ }^{1}$ Université du Québec à Montréal, ${ }^{2}$ Groupe de Recherche en Écologie Comportementale et Animale, Département des sciences \\ biologiques, Université du Québec à Montréal, ${ }^{3}$ Pierre Mousseau Biologiste-Conseil
}

\begin{abstract}
Understanding how birds cope with climate change has received much attention in recent years. So far, more emphasis has been given to passerine species than to any other groups of birds, possibly because of the availability of long-term data sets. Our objective was to study the effect of climate change on spring arrival date and breeding chronology of Ring-billed Gulls (Larus delawarensis), a short-distance migrant with a diverse diet. Based on Étude des Populations d'Oiseaux du Québec (EPOQ) checklists, we found that gulls arrived in southern Québec five days earlier in 2012 than in 1971. Sporadic observations in three nearby colonies indicated that Ring-billed gulls laid eggs eight days earlier in 2012 than they did in 1978. Both arrival and laying dates closely fit temperature warming. Because of their diverse diet, Ring-billed Gulls always have access to some food resources during the breeding period making a mismatch between phenology and food abundance unlikely. Continuous warming may enhance the use of agricultural lands by gulls before and during the breeding period. However, this may not be sufficient to compensate for a reduction of refuse accessibility at landfills that have implemented deterrence programs.
\end{abstract}

\section{Modifications des dates d'arrivée printanière et de reproduction des Goélands à bec cerclé dans le sud du Québec sur une période de quatre décennies}

RÉSUMÉ. La compréhension de l'ajustement des oiseaux aux changements climatiques a reçu beaucoup d'attention durant les dernières années. Jusqu'à présent, ce sont surtout les espèces de passereaux qui ont fait l'objet de recherches, possiblement en raison de la disponibilité de longues séries de données. Notre objectif était d'étudier l'effet des changements climatiques sur la chronologie de migration printanière et la reproduction des Goélands à bec cerclé (Larus delawarensis), un migrateur de courte distance et à la diète variée. Au moyen des données d'Étude des Populations d'Oiseaux du Québec (ÉPOQ), nous avons trouvé que les goélands arrivaient dans le sud du Québec cinq jours plus tôt en 2012 qu'en 1971. À partir d'observations sporadiques dans trois colonies situées à proximité l'une de l'autre, nous avons observé qu'en 2012, les goélands pondaient huit jours plus tôt qu'en 1978. Les dates d'arrivée et de ponte étaient fortement liées au réchauffement de la température. Grâce à leur diète variée, les Goélands à bec cerclé ont toujours accès à des sources de nourriture durant leur reproduction; un désajustement entre la phénologie et l'abondance de nourriture est donc peu probable chez cette espèce. Le réchauffement continu pourrait favoriser une plus grande accessibilité des terres agricoles pour les goélands avant et pendant leur reproduction. Cependant, cette possibilité pourrait ne pas être suffisante pour compenser la réduction de l'accès aux déchets dans les sites d'enfouissement où des programmes d'effarouchement sont en place.

Key Words: climate change, Larus delawarensis; migration; phenology; population dynamics; rainfall; reproduction; temperature; warming

\section{INTRODUCTION}

Climate change has been linked to shifts in phenology for many species (Parmesan 2007). Global warming induces changes in local weather and environmental conditions, modifying the optimal timing of life-history events. Temperature en route or at breeding ground destinations is considered the most reliable cue used by birds to time their spring migration (Both et al. 2005). With temperature warming at temperate latitudes, there is much evidence that many species are advancing their migration and breeding schedule although some species have not yet responded or have delayed these events (Butler 2003, Ellwood et al. 2010, Hurlbert and Liang 2012). So far, more emphasis has been given to smaller passerine species possibly because of the availability of long-term data sets. However, understanding how other groups of birds respond to climate changes may help to determine the underlying mechanisms and consequences.

Besides the constraints of endogenous and circannual rhythms, life-history and ecological traits may also explain differences in arrival dates. For instance, short-distance migrants generally advance their arrival date on the breeding grounds at a faster rate than long-distance migrants (Végvári et al. 2010, Saino et al. 2011). It has been suggested that these species can more easily assess changes in weather conditions at their destination compared with birds wintering further south that must rely on more general cues to initiate their migration. Furthermore, Végvári et al. (2010) have found that generalist feeders might be 
able to better respond to climate change because they can more easily find appropriate food during migration and upon arrival on the breeding grounds. They can also feed their offspring during a longer period of food availability compared with specialists that must match a short burst of resources to feed their young as observed for many migratory insect-eating passerines (Visser et al. 2006).

Mismatch of seasonal events such as migration and breeding with resource availability can greatly affect reproductive output of animals and thus population dynamics (Durant et al. 2007, Møller et al. 2008, Both et al. 2010). In migratory birds, the optimal date of spring arrival is crucial because individuals arriving too soon on their breeding grounds may encounter suboptimal weather conditions and be confronted by a lack of food resources. Alternatively, those arriving too late may be restricted to poor quality nest sites and may face food shortages if competitors are present or if they miss the peak of food availability. Population declines are thus expected for species that cannot adjust their phenology (Saino et al. 2011).

Our first objective was to evaluate the effect of climate change on arrival date on the breeding grounds of a short-distance migrant with a diverse diet, the Ring-billed Gull (Larus delawarensis). We studied a population that breeds on islands in the Saint-Lawrence River in southern Québec and winters in eastern United States (Pollet et al. 2012), which is considered a short-distance migration (Butler 2003). These gulls feed on a wide variety of items including food waste from landfills, annelids, and arthropods (Lagrenade and Mousseau 1981, Brousseau et al. 1996, Caron-Beaudoin et al. 2013). Increasing temperatures and rainfall should contribute to earlier snowmelt and soil thawing providing earlier access to agricultural fields that are preferentially used by nesting Ringbilled gulls (Patenaude-Monette et al. 2014). We therefore predicted that temperature increases and rainfall should incite the gulls to arrive earlier in southern Québec because they would be able to forage in agricultural fields earlier in spring.

The second objective was to look at the effect of changes in arrival date and climate on the timing of breeding. Earthworms are important for egg production because they are composed of $60-70 \%$ proteins (Houston et al. 1983, Edwards et al. 2011). Greater earthworm availability associated with increased temperatures and rainfall (Sibly and McCleery 1983) should provide nutrients that would allow the gulls to initiate their clutch earlier. Increased temperature, rainfall, and the opening of the Saint-Lawrence Seaway should also break ice-bridges around insular colonies thus supplying secure nest sites earlier in the season. We thus predicted an advance in the timing of breeding as a response to an earlier arrival and an increase in temperature.

\section{METHODS}

\section{Study area}

We conducted our study in the Montreal metropolitan community (CMM) that covers $4360 \mathrm{~km}^{2}$ and is home to $\sim 3.7$ million people. Land use includes farmland $(55 \%$ of the total area), woodlots $(21 \%)$, urban areas $(18 \%)$, and waterways $(5 \%$; Patenaude-Monette et al. 2014). The majority of Ring-billed Gulls nest in five colonies located on islands in the Saint-Lawrence
River. The breeding phenology was studied in three colonies located within $50 \mathrm{~km}$ of each other and that supported over $90 \%$ of the nesting pairs. Île Deslauriers $\left(45.712^{\circ} \mathrm{N}, 73.440^{\circ} \mathrm{W}\right)$ located $3 \mathrm{~km}$ northeast of Montréal is the largest colony with 44,000-51,000 pairs during the study. The second colony located just south of Montréal is Île de la Couvée $\left(45.474^{\circ} \mathrm{N}, 73.506^{\circ} \mathrm{W}\right)$. Gulls colonized the island in the early 1970s but abandoned it in 2007-2008. There were about 11,000 pairs during the study. Finally, Île de la Petite Colonie $\left(45.890^{\circ} \mathrm{N}, 73.227^{\circ} \mathrm{W}\right)$ is part of the Îles de Contrecoeur National Wildlife Area located $27 \mathrm{~km}$ northeast of Montreal and supported 8600 pairs at the time of the study.

The first Ring-billed Gulls arrive in the Montreal area in early to mid-March and they occupy the breeding colonies from April to July. A significant proportion of breeders disperse in July and August downstream along the Saint-Lawrence River, upstream toward the Great Lakes region, or directly to the USA Atlantic Coast before reaching their wintering grounds that range from Massachusetts to Florida (Pollet et al. 2012; C. Girault and J.-F. Giroux, personal observation).

\section{Arrival date}

We used data from Étude des Populations d'Oiseaux du Québec (EPOQ) to determine spring arrival dates of Ring-billed Gulls in southern Québec between 1971 and 2012 (Dunn et al. 1996). This database is made up of checklists filled by volunteer observers who report the number of birds by species seen or heard at a specific location on a single day. We selected checklists submitted during March and April for the region that included the main Ring-billed Gull colonies within the CMM. The focal region was determined by merging the areas located within a $63-\mathrm{km}$ radius around each colony, which corresponds to the maximum direct foraging distance traveled by nesting gulls (Patenaude-Monette et al. 2014). The annual number of checklists with a Ring-billed Gull sighting for these two months averaged $234 \pm 150$ ( \pm SD; range: $15-490)$. Detection probabilities are expected to vary according to observers, survey duration, environmental conditions, and spatial coverage. Nevertheless, Ring-billed Gulls should have a high probability of detection because they are conspicuous, easy to identify, and relatively abundant. The large number of observers in the CMM and their high participation during spring migration should guarantee a minimum sampling effort and a representative coverage regardless of annual variation in weather conditions.

Because a few Ring-billed Gulls winter in southern Québec, we could not assess changes in spring arrival by modeling date of the first checklist with a Ring-billed Gull sighting. Furthermore, first arrival is strongly influenced by outliers, sampling effort, and population size (Miller-Rushing et al. 2008). Instead, we estimated the population-level arrival date by computing the cumulative number of lists with at least one sighting of Ringbilled Gull between 1 March and 30 April and used the date at which $50 \%$ of the lists had reported the species as an approximation of the median arrival date. We could not distinguish sightings of Ring-billed Gulls breeding in the study area from those en route to other breeding sites or of nonbreeding birds. However, $86 \%$ of all Ring-billed Gulls breeding in southern Québec are found within the CMM (Cotter et al. 2012). 


\section{Laying date}

We monitored the breeding chronology of Ring-billed Gulls on Île de la Couvée in 1978 and 2000 (PM), on Île de la Petite Colonie in 1979 (PM), and on Île Deslauriers from 2009 to 2012 (FR, FL, and MP-M). Because of the proximity of these colonies, we assumed that the nesting birds were exposed to similar climatic conditions. Three to eight circular plots of $2.5-5.0 \mathrm{~m}$ in radius were established in each colony using the multiple visits methodology described by Mousseau (1984). Plots were visited as soon as the first eggs were laid and every 2-4 days thereafter until the young had fledged. Each nest was identified with a numbered flag and eggs were numbered in laying sequence with a nontoxic permanent marker. At each visit, new nests, the number of eggs in the marked nests, and the fate of the marked eggs were recorded. We assumed that a nest with one egg had been initiated earlier that day and the date was considered the clutch initiation date. Nests found with two or more freshly laid eggs were backdated assuming a laying interval of two days (Pollet et al. 2012). Nests that were first located after incubation commenced and that had a known hatching date were included in the sample by subtracting 27 days from the hatching date assuming that partial incubation starts after the first laid egg (Pollet et al. 2012). We monitored 128-386 nests each year $($ mean $=276 ; \mathrm{SD}=95)$ for a total of 1932 nests with a known initiation date ( \pm 1 day) during the seven years. For each year, we computed the median nest initiation date of the marked nests.

\section{Environmental variables}

We calculated mean temperature, total snowfall, and total rainfall for March and April 1971-2012 using daily observations from six meteorological stations located throughout the CMM on both shores of the Saint-Lawrence River (Dorval, Joliette, Lachute, Sainte-Martine, Saint-Hubert, and Saint-Jérôme). Data were retrieved from Environment Canada website (http://climate. weather.gc.ca/index_e.html\#access). The annual opening dates of the Saint-Lawrence River Seaway were used to determine the timing of ice break-up on the river and were obtained from the St. Lawrence Seaway Management Corporation (St. Lawrence Seaway Management Corporation 1992, 2012).

\section{Statistical analyses}

We first fit a linear model between spring arrival date and year to test whether Ring-billed gulls arrived progressively sooner in southern Québec. To determine factors that may explain change in gulls' arrival date over time, we used the approach described by Smith and Gaston (2012). We built a series of 17 linear models based on our a priori predictions that temperature and precipitation should affect arrival date by modifying food availability. The models included the main effects of mean daily temperature recorded in March-April (MTMA), total snowfall in March-April (TSMA), total rainfall in March-April (TRMA), and the opening date of the Saint-Lawrence Seaway (SLSO). Because temperature was our primary interest, we added MTMA to the other environmental variables to test additive effects. Because some variables showed linear trends over time, there was potential for spurious correlations and we therefore used the residual regression method (Graham 2003). Detrended variables were considered by using residuals of linear models that regressed the environmental variables against year (Grosbois et al. 2008).
In a second analysis, the same set of candidate models was then considered using these detrended variables. Models including environmental covariates were tested against both a null model and a model with a linear temporal trend (YEAR) using the second-order Akaike information criterion (AIC, Burnham and Anderson 2002) with the AICcmodavg package run in the $\mathrm{R}$ statistical environment (Mazerolle 2015).

We used the same approach to explain variation in laying date although the available data were limited to seven years in three colonies. A total of 14 models based on our initial predictions that laying date was affected by the availability of nutrient-rich food and secure nest sites on islands were tested against both a null model and a model with a linear temporal trend (YEAR). These models included spring median arrival date (MAD), mean daily temperature in April (MTA), total rainfall in April (TRA), and the opening of the Saint-Lawrence Seaway (SLSO) as main effects. We also added MTA to the other variables to test additive effects. As for arrival date, a second set of models with detrended variables was also tested to explain variation in laying date. As an overall assessment of climate change in southern Québec, we fit a linear model between mean daily temperature in March-April and years to assess changes in temperature between 1971 and 2012.

\section{RESULTS}

\section{Spring arrival}

We found a significant negative trend of spring arrival date of Ring-billed Gulls in southern Québec between 1971 and 2012 ( $\beta$ $=-0.126 \pm 0.030 ; \mathrm{r}^{2}=0.31, F_{1,40}=18.0, P<0.001 ;$ Fig. 1A). The linear model showed that gulls arrived $0.13 \pm 0.03$ day sooner each year. The predicted median arrival date advanced by five days during the 42-year period and was 8 April 2012 (leap year) compared with 14 April 1971. The top model to explain variation in arrival date included mean daily temperature in March-April and a year effect (Table 1). The next three models that had nearly as much support included these two variables plus total snow and total rain in March-April and the opening date of the SaintLawrence Seaway. These four models together had a cumulative $\omega_{i}$ of 0.84 and were superior to both the null model and the model with a linear temporal trend only (Table 1 ).

Mean temperature in March-April and the opening date of the seaway showed significant temporal trends and were correlated to each other $\left(\beta=-1.408 \pm 0.437 ; \mathrm{r}^{2}=0.20, F_{1,40}=10.4, P=0.003\right)$. In a second set of models, we thus used detrended values for these two variables to look only at fluctuations from the trend over time. Ranking of top models using detrended values was similar to the ranking of models based on original variables (Table A1.1). This lent further support that temperature explained variation in arrival date. However, the inclusion of YEAR in both top models indicated that other unmeasured variables that also showed a trend over time during the study period may have an effect.

Based on the regression slope, the median spring arrival date has advanced by $1.0 \pm 0.2$ day for each warming of $1^{\circ} \mathrm{C}(\beta=-1.042$ $\pm 0.191 ; \mathrm{r}^{2}=0.43, F_{1,40}=29.7, P<0.001 ;$ Fig. 1B). Finally, the mean daily temperature recorded in March-April in southern Québec increased by $2.3^{\circ} \mathrm{C}$ between 1971 and $2012(\beta=0.056$ $\pm 0.021 ; \mathrm{r}^{2}=0.15, F_{1,40}=7.2, P=0.010$; Fig. A1.1). 
Fig. 1. Spring median arrival date of Ring-billed Gulls (Larus delawarensis) in southern Québec determined from Étude des Populations d'Oiseaux du Québec (EPOQ), 1971-2012, (A) and the relationship with mean daily temperature in March-April (B). The solid line represents the regression function while the dashed lines represent the $95 \%$ confidence intervals.

A

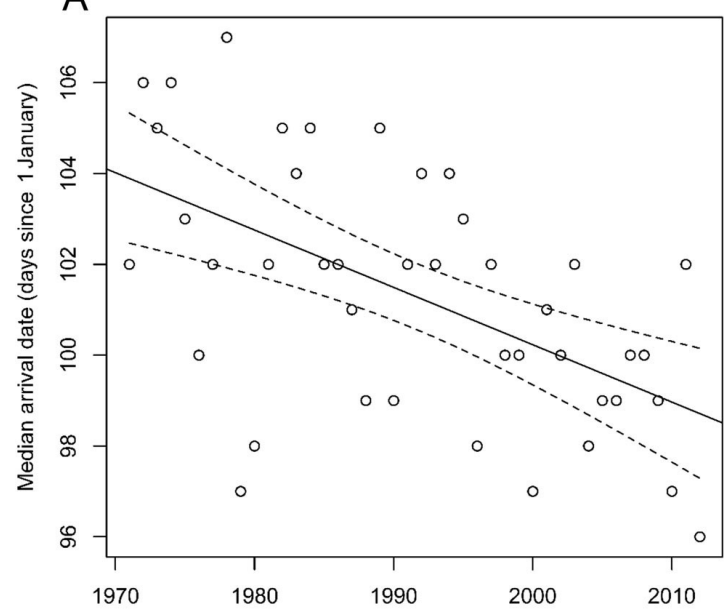

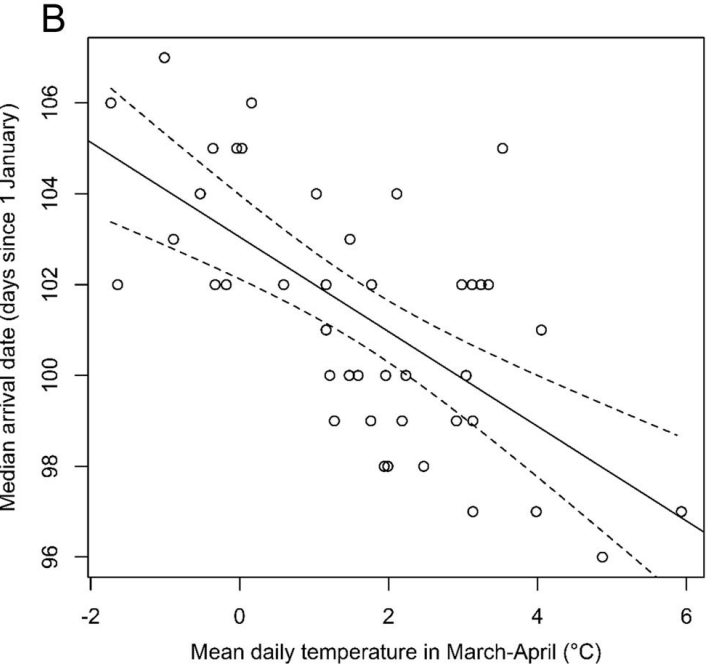

Table 1. Ranking of models explaining variation in median spring arrival date of Ring-billed Gulls (Larus delawarensis) in southern Québec determined from Étude des Populations d'Oiseaux du Québec (EPOQ), 1971-2012.

\begin{tabular}{lcccc}
\hline \hline Model $^{\dagger}$ & $\mathrm{k}$ & $\Delta$ AICc & $\omega \mathrm{i}$ & $\begin{array}{c}\text { Log- } \\
\text { Likelihood }\end{array}$ \\
\hline MTMA + YEAR & 4 & 0 & 0.44 & -86.02 \\
MTMA + TRMA + YEAR & 5 & 2.347 & 0.14 & -85.90 \\
MTMA + SLSO + YEAR & 5 & 2.353 & 0.14 & -85.90 \\
MTMA + TSMA + YEAR & 5 & 2.560 & 0.12 & -86.01 \\
MTMA + SLSO + TRMA + YEAR & 6 & 4.932 & 0.04 & -85.83 \\
MTMA + TSMA + SLSO + YEAR & 6 & 5.068 & 0.04 & -85.89 \\
MTMA + TSMA + TRMA + YEAR & 6 & 5.071 & 0.04 & -85.89 \\
MTMA & 3 & 6.263 & 0.02 & -90.37 \\
MTMA + SLSO & 4 & 7.574 & 0.01 & -89.81 \\
MTMA + TRMA & 4 & 8.118 & 0.01 & -90.08 \\
MTMA + TSMA & 4 & 8.461 & 0.01 & -90.25 \\
MTMA + SLSO + TRMA & 5 & 9.299 & 0 & -89.37 \\
MTMA + TSMA + SLSO & 5 & 9.923 & 0 & -89.69 \\
MTMA + TSMA + TRMA & 5 & 10.541 & 0 & -90.00 \\
YEAR & 3 & 13.968 & 0 & -94.23 \\
SLSO & 3 & 21.992 & 0 & -98.24 \\
TSMA & 3 & 26.307 & 0 & -100.40 \\
Null & 2 & 27.269 & 0 & -102.04 \\
TRMA & 3 & 29.230 & 0 & -101.86 \\
\hline
\end{tabular}

${ }^{\dagger}$ MTMA: mean daily temperature in March-April; SLSO: St. Lawrence Seaway opening date; TRMA: total rain in March-April; TSMA: total snow in March-April; YEAR: year; the lowest AIC was 181.12 and $\mathrm{N}$ $=42$.

\section{Laying date}

Laying dates tended to advance with time $\left(\beta=-0.231 \pm 0.087 ; \mathrm{r}^{2}\right.$ $=0.59, F_{1.5}=7.06, P=0.045$; Fig. $\left.2 \mathrm{~A}\right)$ and the model predicted that gulls laid their eggs eight days earlier in 2012 (last year with
Table 2. Ranking of models explaining variation in the median laying date of Ring-billed Gulls (Larus delawarensis) at Île de la Couvée (1978, 2000), Petite Colonie (1979), and Île Deslauriers (2009-2012).

\begin{tabular}{lcccc}
\hline \hline Model $^{\dagger}$ & $\mathrm{k}$ & $\Delta \mathrm{AICc}$ & $\omega \mathrm{i}$ & $\begin{array}{c}\text { Log- } \\
\text { Likelihood }\end{array}$ \\
\hline MTA & 3 & 0 & 0.94 & -9.52 \\
MTA + SLSO & 4 & 6.331 & 0.04 & -5.69 \\
MTA + YEAR & 4 & 8.450 & 0.01 & -6.75 \\
MTA + TRA & 4 & 12.008 & 0 & -8.53 \\
MTA + MAD & 4 & 13.600 & 0 & -9.32 \\
null & 2 & 14.050 & 0 & -20.05 \\
YEAR & 3 & 14.930 & 0 & -16.99 \\
MAD & 3 & 16.649 & 0 & -17.85 \\
SLSO & 3 & 18.273 & 0 & -18.66 \\
TRA & 3 & 20.578 & 0 & -19.81 \\
MTA + TRA + SLSO & 5 & 45.146 & 0 & -4.10 \\
MTA + MAD + SLSO & 5 & 46.073 & 0 & -4.56 \\
MTA + TRA + YEAR & 5 & 47.848 & 0 & -5.45 \\
MTMA + SLSO + YEAR & 5 & 47.993 & 0 & -5.52 \\
MTA + MAD + YEAR & 5 & 49.985 & 0 & -6.52 \\
MTA + TRA + MAD & 5 & 53.417 & 0 & -8.23 \\
\hline${ }^{\dagger}$ MTA: mean daily temperature in April; SLSO: St. Lawrence Seaway \\
Opening date; TRA: total rain in April; MAD: median arrival date; \\
YEAR: year; the lowest AIC ${ }_{\mathrm{c}}$ was 33.05 and N = 7. & \\
\end{tabular}

data) compared with 1978 (first year with data). However, the relationship became nonsignificant when removing the 1978 data point $\left(\beta=-0.130 \pm 0.098 ; \mathrm{r}^{2}=0.30, F_{1,4}=1.75, P=0.256\right)$. The best model to explain variation in laying date included mean temperature in April $\left(\omega_{i}=0.94\right.$; Table 2$)$. It showed that for each increase of $1{ }^{\circ} \mathrm{C}$, the laying date advanced by $2.5 \pm 0.3$ days $(\beta$ $=-2.542 \pm 0.252 ; \mathrm{r}^{2}=0.95, F_{1,5}=102.0, P<0.001 ;$ Fig. $\left.2 \mathrm{~B}\right)$. The 
Fig. 2. Median nest initiation date of Ring-billed Gulls (Larus delawarensis) at Île de la Couvée (1978, 2000), Petite Colonie (1979), and Île Deslauriers (2009-2012) (A), and the relationship with mean daily temperature in April (B). The solid line represents the regression function while the dashed lines represent the $95 \%$ confidence intervals.
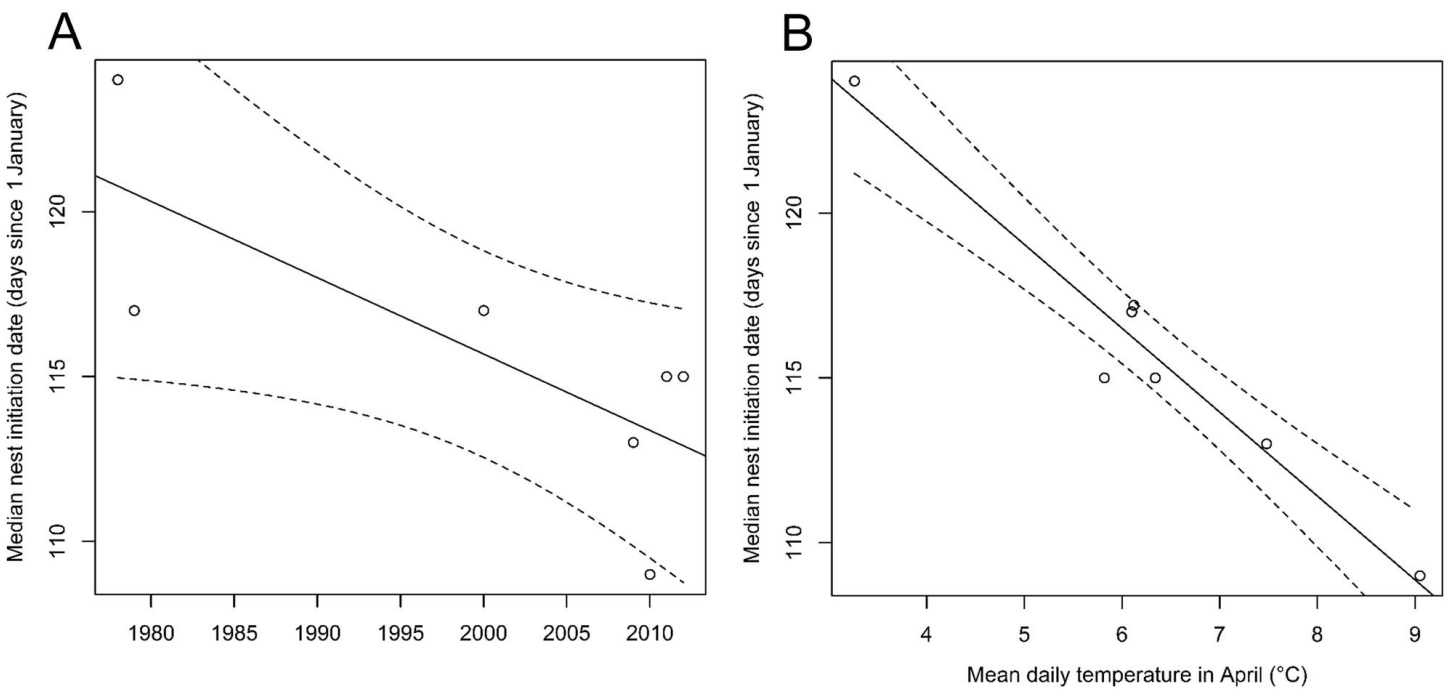

other models that included opening date of the Saint-Lawrence Seaway, total rainfall in April, and arrival date had little support (cumulative $\omega_{i}=0.06$ ).

Using the 1978-2012 data, only the seaway opening date showed a significant trend over time. We thus built another set of models using detrended values for SLSO and confirmed that the model with mean daily temperature in April still had the greatest support (Table A1.2).

\section{DISCUSSION}

Strong competition for territories and low mortality risk after arrival on the breeding grounds should favor an early optimal arrival date in birds (Jonzén et al. 2007). This applies to Ringbilled Gulls that usually nest on mammalian-free insular colonies of several thousand pairs that must establish and defend territories. With warming spring temperature over the last four decades, the gulls now arrive five days earlier on their breeding grounds in southern Québec. However, the correlation between temperature and phenology cannot be necessarily interpreted as a causal relationship as indicated by the inclusion of year in the top models. This suggests that other environmental variables that showed similar temporal trends could influence arrival date. Ringbilled Gulls also advanced their laying date between 1978 and 2012 and this was strongly associated with mean daily temperature in April. Because laying date advanced twice as rapidly than arrival date for a similar warming of temperature, the prelaying period must be shorter.

We found no correlation between snowfall in spring and arrival or laying dates. Vermeer (1970) observed that the arrival of Ringbilled Gulls in Alberta was not associated with snow cover but possibly with a minimal air temperature threshold. Increased temperatures can accelerate snowmelt and free up nest sites earlier. The islands that support the gull colonies become safer after ice break-up because they are less accessible to mammalian predators. The opening of the Saint-Lawrence Seaway took place 11 days earlier in 2012 than in 1971 and this variable was correlated with median arrival date but not laying date. In general, ice breakup takes place shortly after arrival of the first individuals and 2-3 weeks before laying. Nevertheless, earlier ice break-up on the Saint-Lawrence River provides additional food resources such as invertebrates, small fish, and various refuse during the prelaying period. Pairs are often seen loafing on small pieces of floating ice or feeding on debris piled up along the shores (J.-F. Giroux, personal observation).

Marteinson et al. (2015) found that field metabolic rate of Ringbilled Gulls was affected when birds were exposed to temperatures below their lower critical temperature (LCT), a threshold under which heat loss exceeds energy production at rest. Climate warming during the past decades has probably reduced the amount of time that gulls spent below LCT, thus lessening their energy requirements and possibly the amount of food needed.

Sightings and satellite tracking of Ring-billed Gulls marked in Québec colonies indicate that a significant proportion of birds winter in Massachusetts, Connecticut, New York, New Jersey, Pennsylvania, and Virginia (C. Girault and J.-F. Giroux, personal observation). This represents distances of $450-1000 \mathrm{~km}$ to the breeding grounds, which clearly categorizes this species as a shortdistance migrant (Butler 2003). Several studies have reported that birds migrating over short distances have advanced their arrival date on the breeding grounds more than long-distance migrants although this is not a universal rule (Gienapp et al. 2007, Végvári et al. 2010, Knudsen et al. 2011, Saino et al. 2011). Nonetheless, it appears that Ring-billed Gulls are able to track temperature changes on the breeding grounds from their wintering areas. However, it is unknown whether the birds winter further north as a result of climate warming. The effect of temperature on the 
departure date from the wintering areas in early spring is also unknown and will be investigated through our satellite tracking.

Based on a meta-analysis including the omnivorous Yellowlegged Gull (Larus michahellis), Végvári et al. (2010) concluded that generalist species with a varied diet were advancing their arrival date in response to warming to a greater extent than specialists. We have no specific information on habitat use and diet of Ring-billed gulls while en route to their breeding grounds or during prelaying. However, they have a diverse diet during the breeding period and there is some indication based on isotope analyses that Ring-billed gull individuals may conserve dietary habits throughout this period (Brousseau et al. 1996, CaronBeaudoin et al. 2013). We can thus assume that Ring-billed Gulls have access to, and feed on a variety of items during migration and upon arrival on the breeding grounds, which may facilitate the advancement of migration timing and laying in response to increasing temperatures.

Patenaude-Monette et al. (2014) determined that nesting Ringbilled Gulls preferentially forage on earthworms and seeds found in agricultural fields that become snow free and thus accessible earlier with warmer spring temperatures. Precipitations also influence arrival but not laying dates. However, no temporal trends were established for either the total amount of snow or rain in March-April. Rainfall and thus soil humidity are associated with a greater earthworm availability (Sibly and McCleery 1983). As soils dry out with warmer temperatures, earthworms move deeper into the soil where they are less accessible to gulls until they become temporarily available when soil preparation, e.g., ploughing, harrowing, disking, takes place. This is accomplished by heavy machinery that can only operate when fields are sufficiently dry. There is therefore a complex and dynamic process that links weather, food availability in agricultural fields, and gull phenology. Ring-billed Gulls also select landfills and waste transhipment sites where they feed on refuse (Patenaude-Monette et al. 2014). These food sources are always available but easier to obtain when temperatures are above freezing. It is therefore unlikely that by advancing their laying date, Ring-billed Gulls have access to less food resources for them or their offspring. This reduces the possibility of a mismatch between the timing of breeding and the peak of food abundance, which has been associated to population declines of several species (Mills et al. 2008, Møller et al. 2008, Saino et al. 2011).

The number of Ring-billed Gulls in the colonies located within the CMM has not followed a monotonic trend with temperature. It increased from 22,000 breeding pairs in the late 1970s to 96,000 in the mid-1990s and then declined to 76,000 in 2012 (Giroux et al. 2016). The decline has been attributed to a reduction in chick survival between the 1980s when the population was growing and 2009-2012 (Mousseau 1984, Giroux et al. 2016). The increased accessibility to agriculture fields with warming temperatures does not appear to compensate for the loss of feeding opportunities at a major nearby landfill where an effective deterrence program based on falconry has been implemented (Thiériot et al. 2015). Similarly, Glaucous-winged Gulls (Larus glaucescens) have been unable to compensate for a reduction of their main food (forage fish), which results in delayed laying, reduced clutch size and chick survival, and a concomitant population decline (Blight 2011, Blight et al. 2015). Food availability may therefore have a greater effect on population dynamics of gulls than climate change per se.
In conclusion, Ring-billed Gulls appear to adjust their timing of arrival on the breeding grounds and laying in response to increased temperatures. Because of their diverse diet, the gulls always have access to some food resources during the breeding period reducing the possibility of a mismatch between phenology and food abundance. Continuous warming may increase the use of agricultural lands before and during the breeding period. However, this does not appear to allow the gulls to compensate for a reduction of refuse accessibility at landfills that may contribute to a general population decline. We do not know whether Ring-billed Gulls leave southern Québec earlier for their postbreeding dispersal or fall migration, especially if they fledge young earlier. If they leave earlier, their total time in Québec would be the same. On the other hand, if they leave at the same time or later because of mild weather, their presence would be longer and this may generate more nuisance problems (Thieriot et al. 2015), which could represent an indirect effect of global warming.

Responses to this article can be read online at: http://www.ace-eco.org/issues/responses.php/821

\section{Acknowledgments:}

We are very grateful to F. Allaire, N. David, S. Duchesne, C. Girault, M.-C. Lagrenade, J. Lavigne, A. Morrier, A. Schmutz, F. St-Pierre, E. Thiériot, and M. Tremblay for assistance with field work. We thank C. Girault, S. C. Marteinson, and two anonymous reviewers for constructive comments on an earlier version of the manuscript. Nest monitoring methods were approved by the Institutional Animal Protection Committee of the Université du Québec à Montréal (No. 646) in accordance with the Canadian Council on Animal Care. Financial support was provided by the Natural Sciences and Engineering Council of Canada through scholarships to $F$. R. and M. P. M. as well as a Discovery and Collaborative Research and Development grants to J.-F. G. Additional funding was provided by the Canadian Wildlife Service of Environment Canada, Waste Management, BFI Canada, Chamard et Associés, Falcon Environmental Services, I.C.I. Environnement and Ville de Montréal.

\section{LITERATURE CITED}

Blight, L. K. 2011. Egg production in a coastal seabird, the Glaucous-winged Gull (Larus glaucescens), declines during the last century. PLoS ONE 6:e22027. http://dx.doi.org/10.1371/ journal.pone.0022027

Blight, L. K., M. C. Drever, and P. Arcese. 2015. A century of change in Glaucous-winged Gull (Larus glaucescens) populations in a dynamic coastal environment. Condor 117:108-120. http://dx. doi.org/10.1650/CONDOR-14-113.1

Both, C., R. G. Bijlsma, and M. E. Visser. 2005. Climatic effects on timing of spring migration and breeding in a long-distance migrant, the Pied Flycatcher Ficedula hypoleuca. Journal of Avian Biology 36:368-373. http://dx.doi.org/10.1111/j.0908-8857.2005.03484. $\mathrm{x}$

Both, C., C. A. M. Van Turnhout, R. G. Bijlsma, H. Siepel, A. J. Van Strien, and R. P. B. Foppen. 2010. Avian population 
consequences of climate change are most severe for long-distance migrants in seasonal habitats. Proceedings of the Royal Society of London B 277:1259-1266. http://dx.doi.org/10.1098/rspb.2009.1525

Brousseau, P., J. Lefebvre, and J.-F. Giroux. 1996. Diet of Ringbilled Gull chicks in urban and non-urban colonies in Quebec. Colonial Waterbirds 19:22-30. http://dx.doi.org/10.2307/1521803

Burnham, K. P., and D. R. Anderson. 2002. Model selection and multimodel inference: a practical information-theoretic approach. Second edition. Springer-Verlag, New York, New York, USA. http://dx.doi.org/10.1007/b97636

Butler, C. J. 2003. The disproportionate effect of global warming on the arrival dates of short-distance migratory birds in North America. Ibis 145:484-495. http://dx.doi.org/10.1046/

j.1474-919X.2003.00193.x

Caron-Beaudoin, É., M.-L. Gentes, M. Patenaude-Monette, J.F. Hélie, J.-F. Giroux, and J. Verreault. 2013. Combined usage of stable isotopes and GPS-based telemetry to understand the feeding ecology of an omnivorous bird, the Ring-billed Gull (Larus delawarensis). Canadian Journal of Zoology 91:689-697. http://dx.doi.org/10.1139/cjz-2013-0008

Cotter, R. C., J. F. Rail, A. W. Boyne, G. J. Robertson, D. V. C. Weseloh, and K. G. Chaulk. 2012. Population status, distribution, and trends of gulls and kittiwakes breeding in eastern Canada, 1998-2007. Canadian Wildlife Service Occasional Paper 120:1-93.

Dunn, E. H., J. Larivée, and A. Cyr. 1996. Can checklist programs be used to monitor populations of birds recorded during the migration season? Wilson Bulletin 108:540-549.

Durant, J. M., D. Ø. Hjermann, G. Ottersen, and N. C. Stenseth. 2007. Climate and the match or mismatch between predator requirements and resource availability. Climate Research 33:271-283. http://dx.doi.org/10.3354/cr033271

Edwards, C. A., N. Q. Arancon, and R. L. Sherman. 2011. Vermiculture technology: earthworms, organic wastes, and environmental management. CRC, Boca Raton, Florida, USA. http://dx.doi.org/10.1201/b10453

Ellwood, E. R., R. B. Primack, and M. L. Talmadge. 2010. Effects of climate change on spring arrival times of birds in Thoreau's Concord from 1851 to 2007. Condor 112:754-762. http://dx.doi. org/10.1525/cond.2010.100006

Gienapp, P., R. Leimu, and J. Merilä. 2007. Responses to climate change in avian migration time - microevolution versus phenotypic plasticity. Climate Research 35:25-35. http://dx.doi. org/10.3354/cr00712

Giroux, J.-F., M. Patenaude-Monette, F. Lagarde, E. Thiériot, P. Brousseau, and P. Molina. 2016. The rise and fall of Ring-billed Gulls (Larus delawarensis) in eastern North America. Waterbirds 39 (Special Publication 1), in press.

Graham, M. H. 2003. Confronting multicollinearity in ecological multiple regression. Ecology 84:2809-2815. http://dx.doi. org/10.1890/02-3114

Grosbois, V., O. Gimenez, J.-M. Gaillard, R. Pradel, C. Barbraud, J. Clobert, A. Møller, and H. Weimerskirch. 2008. Assessing the impact of climate variation on survival in vertebrate populations. Biological Reviews 83:357-399. http://dx.doi.org/10.1111/ j.1469-185X.2008.00047.x

Houston, D. C., P. J. Jones, and R. M. Sinly. 1983. The effect of female body condition on egg laying in Lesser Black-backed Gulls Larus fuscus. Journal of Zoology 200:509-520. http://dx.doi. org/10.1111/j.1469-7998.1983.tb02812.x

Hurlbert, A. H., and Z. Liang. 2012. Spatiotemporal variation in avian migration phenology: citizen science reveals effects of climate change. PLOS ONE 7:e31662. http://dx.doi.org/10.1371/ journal.pone.0031662

Jonzén, N., A. Hedenström, and P. Lundberg. 2007. Climate change and the optimal arrival of migratory birds. Proceedings of the Royal Society of London B 274:269-274. http://dx.doi. org/10.1098/rspb.2006.3719

Knudsen, E., A. Lindén, C. Both, N. Jonzén, F. Pulido, N. Saino, W. J. Sutherland, L. A. Bach, T. Coppack, T. Ergon, P. Gienapp, J. A. Gill, O. Gordo, A. Hedenström, E. Lehikoinen, P. P. Marra, A. P. Møller, A. L. K. Nilsson, G. Péron, E. Ranta, D. Rubolini, T. H. Sparks, F. Spina, C. E. Studds, S. A. Sæther, P. Tryjanowski, and N. C. Stenseth. 2011. Challenging claims in the study of migratory birds and climate change. Biological Reviews 86:928-946. http://dx.doi.org/10.1111/j.1469-185X.2011.00179. $\mathrm{x}$

Lagrenade, M.-C., and P. Mousseau. 1981. Alimentation des poussins de Goélands à bec cerclé de l'Île de la Couvée, Québec. Le Naturaliste Canadien 108:131-138.

Marteinson, S. C., J.-F. Giroux, J.-F. Hélie, M.-L. Gentes, and J. Verreault. 2015. Field metabolic rate is dependent on time-activity budget in Ring-billed Gulls (Larus delawarensis) breeding in an anthropogenic environment. PLOS ONE 10:e0126964. http://dx. doi.org/10.1371/journal.pone.0126964

Mazerolle, M. J. 2015. AICcmodavg: model selection and multimodel inference based on $(Q) A I C(c)$. $\mathrm{R}$ package version. 2.0-3 edition. R Foundation for Statistical Computing, Vienna, Austria.

Miller-Rushing, A. J., T. L. Lloyd-Evans, R. B. Primack, and P. Satzinger. 2008. Bird migration times, climate change, and changing population sizes. Global Change Biology 14:1959-1972. http://dx.doi.org/10.1111/j.1365-2486.2008.01619.x

Mills, J. A., J. W. Yarrall, J. M. Bradford-Grieve, M. J. Uddstrom, J. A. Renwick, and J. Merilä. 2008. The impact of climate fluctuation on food availability and reproductive performance of the planktivorous red-billed gull Larus novaehollandiae scopulinus. Journal of Animal Ecology 77:1129-1142. http://dx. doi.org/10.1111/j.1365-2656.2008.01383.x

Møller, A. P., D. Rubolini, and E. Lehikoinen. 2008. Populations of migratory bird species that did not show a phenological response to climate change are declining. Proceedings of the National Academy of Sciences 105:16195-16200. http://dx.doi. org/10.1073/pnas.0803825105

Mousseau, P. 1984. A comparison of two methods to assess the breeding success of Ring-billed Gulls. Journal of Field Ornithology 55:451-459. 
Parmesan, C. 2007. Influences of species, latitudes and methodologies on estimates of phenological response to global warming. Global Change Biology 13:1860-1872. http://dx.doi. org/10.1111/j.1365-2486.2007.01404.X

Patenaude-Monette, M., M. Bélisle, and J.-F. Giroux. 2014. Balancing energy budget in a central-place forager: which habitat to select in a heterogeneous environment? PLOS ONE 9:e102162. http://dx.doi.org/10.1371/journal.pone.0102162

Pollet, I. L., D. Shutler, J. W. Chardine, and J. P. Ryder. 2012. Ring-billed Gull (Larus delawarensis). In A. Poole, editor. The birds of North America online. Cornell Lab of Ornithology, Ithaca, New York, USA.

Saino, N., R. Ambrosini, D. Rubolini, J. von Hardenberg, A. Provenzale, K. Hueppop, O. Hueppop, A. Lehikoinen, E. Lehikoinen, K. Rainio, M. Romano, and L. Sokolov. 2011. Climate warming, ecological mismatch at arrival and population decline in migratory birds. Proceedings of the Royal Society of London B278:835-842. http://dx.doi.org/10.1098/rspb.2010.1778

Sibly, R. M., and R. H. McCleery. 1983. The distribution between feeding sites of Herring Gulls breeding at Walney Island, U.K. Journal of Animal Ecology 52:51-68. http://dx.doi.org/10.2307/4587

Smith, P. A., and A. J. Gaston. 2012. Environmental variation and the demography and diet of Thick-billed Murres. Marine Ecology Progress Series 454:237-249. http://dx.doi.org/10.3354/ meps09589

St. Lawrence Seaway Management Corporation. 1992. The St. Lawrence Seaway traffic teport - historical tables 1959-1992. The St. Lawrence Seaway Management Corporation, Cornwall, Ontario, Canada.

St. Lawrence Seaway Management Corporation. 2012. The St. Lawrence Seaway traffic report - 2012 navigation season. The St. Lawrence Seaway Management Corporation, Cornwall, Ontario, Canada.

Thiériot, E., M. Patenaude-Monette, P. Molina, and J.-F. Giroux. 2015. The efficiency of an integrated program using falconry to deter gulls from landfills. Animals 5:214-225. http://dx.doi. org/10.3390/ani5020214

Végvári, Z., V. Bókony, Z. Barta, and G. Kovács. 2010. Life history predicts advancement of avian spring migration in response to climate change. Global Change Biology 16:1-11. http://dx.doi. org/10.1111/j.1365-2486.2009.01876.X

Vermeer, K. 1970. Breeding biology of California and Ring-billed Gulls: a study of ecological adaptation to the inland habitat. Canadian Wildlife Service Report Series 12:1-52.

Visser, M. E., L. J. M. Holleman, and P. Gienapp. 2006. Shifts in caterpillar biomass phenology due to climate change and its impact on the breeding biology of an insectivorous bird. Oecologia 147:164-172. http://dx.doi.org/10.1007/s00442-005-0299-6 
Appendix 1 Supplemental material for the paper "Changes in spring arrival date and timing of breeding of Ring-billed Gulls in southern Quebec over four decades" by JeanFrançois Giroux, Martin Patenaude-Monette, Florent Lagarde, Pierre Mousseau, and François Racine.

Table A1.1. Ranking of models explaining variation in median spring arrival date of Ring-billed Gulls in southern Quebec determined from Étude des Populations d'Oiseaux du Québec (EPOQ), 1971-2012.

\begin{tabular}{|c|c|c|c|c|}
\hline Model $\uparrow$ & $\mathrm{k}$ & $\triangle \mathrm{AICc}$ & $\omega \mathrm{i}$ & Log-Likelihood \\
\hline Res_MTMA + YEAR & 4 & 0 & 0.47 & -86.01 \\
\hline Res_MTMA + TRMA + YEAR & 5 & 2.347 & 0.14 & -85.89 \\
\hline Res_MTMA + Res_SLSO + YEAR & 5 & 2.354 & 0.14 & -85.9 \\
\hline Res_MTMA + TSMA + YEAR & 5 & 2.561 & 0.13 & -86 \\
\hline Res_MTMA + Res_SLSO + TRMA + YEAR & 6 & 4.934 & 0.04 & -85.82 \\
\hline Res_MTMA + TSMA + TRMA + YEAR & 6 & 5.071 & 0.04 & -85.89 \\
\hline Res_MTMA + TSMA + Res_SLSO + YEAR & 6 & 5.071 & 0.04 & -85.89 \\
\hline YEAR & 3 & 13.977 & 0 & -94.23 \\
\hline Res_MTMA & 3 & 18.997 & 0 & -96.74 \\
\hline Res_MTMA + Res_SLSO & 4 & 21.308 & 0 & -96.67 \\
\hline Res_MTMA + TRMA & 4 & 21.313 & 0 & -96.67 \\
\hline Res_MTMA + TSMA & 4 & 21.344 & 0 & -96.69 \\
\hline Res_MTMA + TSMA + TRMA & 5 & 23.763 & 0 & -96.6 \\
\hline Res_MTMA + TSMA + Res_SLSO & 5 & 23.778 & 0 & -96.61 \\
\hline Res_MTMA + Res_SLSO + TRMA & 5 & 23.809 & 0 & -96.63 \\
\hline TSMA & 3 & 26.316 & 0 & -100.4 \\
\hline Null & 2 & 27.278 & 0 & -102.04 \\
\hline TRMA & 3 & 29.238 & 0 & -101.86 \\
\hline Res_SLSO & 3 & 29.240 & 0 & -101.86 \\
\hline
\end{tabular}

$\uparrow$ Res_MTMA: residuals of mean temperature in March-April regressed against year;

Res_SLSO: residuals of St. Lawrence Seaway opening date regressed against year; TRMA: total rain in March-April; TSMA: total snow in March-April; YEAR: year; the lowest $\mathrm{AIC}_{\mathrm{c}}$ was 181.109 and $\mathrm{N}=42$. 
Table A1.2. Ranking of models explaining variation in the median laying date of Ringbilled Gulls at Ile de la Couvée (1978, 2000), Petite Colonie (1979), and Île Deslauriers (2009-2012).

\begin{tabular}{lcccc}
\hline Model $\dagger$ & $\mathrm{k}$ & $\Delta$ AICc & $\omega \mathrm{i}$ & Log-Likelihood \\
\hline MTA & 3 & 0 & 0.98 & -9.52 \\
MTA + YEAR & 4 & 8.450 & 0.01 & -6.75 \\
MTA + RES_SLSO & 4 & 11.302 & 0 & -8.17 \\
MTA + TRA & 4 & 12.008 & 0 & -8.53 \\
MTA + MAD & 4 & 13.600 & 0 & -9.32 \\
null & 2 & 14.050 & 0 & -20.05 \\
YEAR & 3 & 14.930 & 0 & -16.99 \\
MAD & 3 & 16.650 & 0 & -17.85 \\
TRA & 3 & 20.578 & 0 & -19.81 \\
RES_SLSO & 3 & 20.919 & 0 & -19.98 \\
MTMA + RES_SLSO + YEAR & 5 & 46.514 & 0 & -4.78 \\
MTA + TRA + YEAR & 5 & 47.848 & 0 & -5.45 \\
MTA + MAD + YEAR & 5 & 49.985 & 0 & -6.52 \\
MTA + TRA + RES_SLSO & 5 & 50.970 & 0 & -7.01 \\
MTA + MAD + RES_SLSO & 5 & 52.004 & 0 & -7.53 \\
MTA + TRA + MAD & 5 & 53.417 & 0 & -8.23 \\
\hline
\end{tabular}

†MTA: mean daily temperature in April; RES_SLSO: residuals of St. Lawrence Seaway opening date regressed against year; TRA: total rain in April; MAD: median arrival date; YEAR: year; the lowest $\mathrm{AIC}_{\mathrm{c}}$ was 33.05 and $\mathrm{N}=7$. 
Fig. A1.1. Mean daily temperature in March-April recorded at five stations in southern Quebec (Dorval, Joliette, Lachute, Sainte-Martine, Saint-Hubert, Saint-Jérôme), 19712012. The solid line represents the regression function while the dashed lines represent the $95 \%$ confidence intervals.

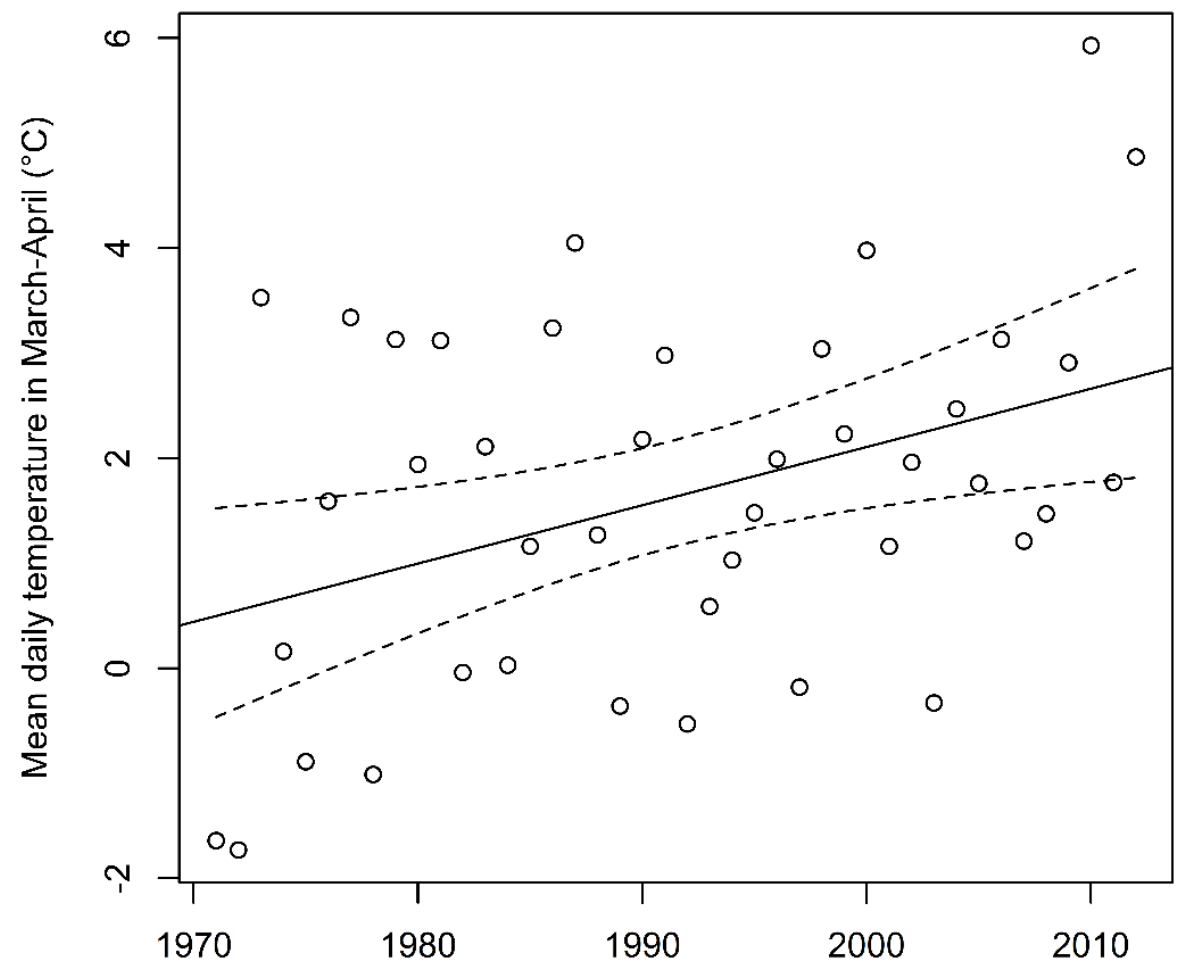

